\title{
Socioeconomic Conditionality of the Baltic Macroregion Landscape Development and Zoning
}

\author{
Elena A. ROMANOVA' \\ ${ }^{1}$ Immanuel Kant Baltic Federal University, Department of Urban Development, Land Management, and Design, Kaliningrad, RUSSIA \\ E-mail: alberta63@mail.ru \\ DOI: 10.24193/JSSP.2017.2.06 \\ https://doi.org/10.24193/JSSP.2017.2.06
}

K e y w o r d s: modern landscapes, Baltic macroregion, landscape genesis, socioeconomic conditionality, territorial and landscape zoning

\begin{abstract}
A B S T RACT
At the regional level, human activity is of the main factors shaping modern landscape. This study considers the features of contemporary landscape development in the Baltic macroregion. A new method of landscape zoning with the use of a synthetic indicator of socioeconomic conditionality is proposed. This indicator shows the degree of anthropogenic differentiation of landscapes within a territory and consists of five components: average population density; forest coverage and agricultural land use; density of road networks and buildings; share of uncultivated land. Based on the proposed methodology, the degree of socioeconomic conditionality in the development of modern landscapes of the Baltic macroregion is determined. The work's practical significance lies in the proposal of a new method of landscape zoning based on settlement and land use practices, which can improve the results of spatial planning on macroregional level.
\end{abstract}

\section{INTRODUCTION}

Consider continents and large tectonic structures and you will find that, along with tectonogenesis, climate is the main global landscapeshaping force. Within each climate zone, the results of tectonogenesis and geological history form the basis of any territorial complex, its lithogenic base and relief, and determine its landscape's genetic form. Two components of landscape, soil and vegetation, largely depend on the conditions of human involvement with the territory: how long, deep and wide the area has been transformed, and how significant the artificially introduced components are. Thus, at the regional level, human activity becomes one of the main factors in the formation of landscapes. From a research perspective, the Baltic macroregion provides an interesting case for a landscape genesis study. Taken narrowly, the region comprises the territories of Sweden, Finland, Estonia, Latvia, Lithuania, Denmark, a number of Russian regions (Leningrad, Pskov, Novgorod and Kaliningrad), several Polish voivodeships (Warmian-Mazury, Pomerania and Western Pomerania), as well as the lands of Mecklenburg-Western Pomerania and Schleswig-Holstein of Germany [7], [22]. Though compact, this territory has a great variety of natural and social geographical phenomena and a good sampling of borders - state, ethnic, linguistic and cultural, all of which are reflected in its present-day landscape. Despite the heterogeneity of this territory in both natural and socioeconomic terms, the "attraction" of local and regional communities to the Baltic Sea in all spheres of life ensures the formation of the Baltic macroregion as a single geographic and geopolitical entity and shapes the "Baltic" identity of its inhabitants [8].

\section{THEORETICAL BACKGROUND}

There are two main approaches in studying the contemporary landscapes. The Russian literature on the subject typically relies on physical geography to tackle 
the issue of human activity as a factor of landscape transformation, with rational land use planning and landscape geoecology being the two most widely used research frameworks. Physical geography determines how one looks at geographical development: for instance, how landscape structure affects settlement or how landscape determines land management, and so on [11].

The western tradition, on the other hand, is embedded in public geography, with human activity as a starting point in studying the environment. The bulk of western landscape research rests in the cultural paradigm. Ever since Carl Sauer, the term "landscape" has been primarily understood in terms of appearance, with all its natural and artificial components; hence, researchers are "reading", or "interpreting" the landscape [30], [18]. Most of the English-language handbooks on landscape interpretation heed to this tradition. Handbook authors' preferences range from landscape being "read" as a history of cultural transformations [35] to emphasizing on the individual impressions of landscape surroundings the author's residence in the English countryside [9]. In their approaches to landscape, some of the handbooks remind the works (not of handbook range, but still) of the Russian authors V. Tishkov (2003) and A. Bikbov (2002). Such is, for example, the volume edited by Mitchell D. (2000), in which he interprets modern landscape as a reflection of power structures, gender policy and racial inequality, leading to his central argument that modern landscape is a purposeful construction [24].

One can also see cultural shift in landscape studies in a number of works related to the preservation of natural and cultural heritage worldwide. In the United States, cultural geography dates back to 1925 [30], and then to the first publications of J. B. Jackson and the birth of his journal, "Landscape" [12]. Among contemporary authors, we should mention M. Dietrich [5], a German researcher, the Canadians G. Swinnerton and S. Buggey [33], and, with certain limitations, the works of the American R. Longstreth [20]. In his February 2015 presentation at the Church and Settlement in Ireland: Landscape, Life and Legacy conference, "Converting the land of the Irish: Saint Patrick, the Church, and the Irish landscape", James Schryver of Minnesota University flipped the common notion of looking at how religion is reflected in the landscape (though focusing on churches and monasteries) by inviting the audience to think, instead, of how the Irish landscape - with its rocky terrain and scarce vegetation - influenced the country's culture, and, by association, religion [31].
Settlement archaeology is yet another area of research in Western geography literature, comprising works relating to the reconstruction of past settlement and agricultural landscapes. Scholars from Great Britain, Estonia and Holland have been doing research in this sphere over the last 10 years [16], [25], [28], [1]. Studies carried out by British authors mostly focus on former settlements, relying heavily on archaeological finds and going as far back as the Iron Age [17]. For example, in Estonia, where archaeological materials are harder to come by, they use natural materials (paleographic and geographical) [26], as well as historical archives from the time of the Swedish rule to reconstruct landscapes and settlement of the $13^{\text {th }}$ century Northern Estonia [13]. Research in Holland focuses more on the reconstruction of the historic land management, since draining the wetlands has always been of outmost importance there [32]. The works mentioned above have all been carried out in different countries and rely on different methods, but they have one thing in common - all of them use scientific data from paleogeography, geoecology, palynology and paleobotany, arguing the impossibility to understand historic lifestyles manifesting in land management and settlement patterns without relating to natural conditions pertaining to settlement areas [15]. Studies on settlement patterns of coastal landscapes of Schleswig-Holstein (Germany) by Mejer D. (2013) are yet another example of this approach [23].

Quite a different approach, still unreplicated in the Russian literature on the subject, can be found in the works of $\mathrm{H}$. Küster, who favours an integrated method. Küster (2004) proposes to call all natural and cultural landscapes simply landscapes, since human influence on landscape formation is almost universal [19]. Küster's research covers a wide range of directions - from studying different landscape-forming processes to looking into the age of cultural landscapes and their secondary succession. We appreciate his argument on the benefits of traditional land management over intensive one for the historically cultivated European lands, as well as the pattern he noticed: if agrolandscapes and agricultural techniques are traditional cultural landscapes are diverse; if agricultural technology is intensive - cultural landscapes are the same; and disappearance of cultural landscape diversity spells the disappearance of local territorial identity.

Our study is an attempt to solve the problem of integrated landscape zoning using a specific geographic region as an example. Such zoning, taking into account both natural and social features of the territory, will allow for a more justified and careful approach to spatial and strategic planning and will thereby ensure 
sustainable development of territorial units of different types.

\section{METHODOLOGY}

Territorial zoning is one of the world's most widely distributed practical spatial planning tools. Spatial planning is the theory and practice determining the status of territories, including rural and urban lands. This can be very specific and depends of many factors: for example, in Bulgaria, agricultural lands are considered national treasure, so repurposing agricultural land is only allowed in exceptional cases and territorial zoning is mostly used to protect a territory status [3].

Territorial zoning is closely connected to landscape zoning, because landscape properties (natural or newly developed anthropogenic) determine the possibilities of using the territories and their value in different aspects of nature management. While city planners and landscape architects have long been interested in landscape properties - at least since the emergence of the so-called "context theory", and especially work of I. McHarg (1969) "Design with Nature" [21], - global scholarship still needs to work out a unified understanding of landscape zoning.

In Russia, one of the most popular concepts of landscape zoning was put forward by A. Isachenko (1991). According to Isachenko, physical geographical, or landscape, zoning combines two series of zonation zonal and azonal. The basic taxonomic unit in the zonal series is a landscape zone, in the azonal series - the physical geographical (landscape) country [10]. At these levels, landscape zoning reflects the features of natural differentiation. Unfortunately, a physical geographical approach to zoning does not scale down well. At the regional level, the state of contemporary landscape is directly dependent on the degree of its development as determined by socioeconomic factors, so settlement and land use become the main landscape-forming systems. While this limitation is obvious, natural-geographical view of the landscape remains popular among researchers of landscape ecology [4].

Landscape definition offered by the European Landscape Convention contrasts those commonly used in landscapes ecology [29]. It explicitly takes human perception of landscapes into account and transfers responsibility for the vision of future landscape development from experts to the community in general, while acknowledging the need of landscape assessment, valuation and management [14].

Landscape management approach (legislative management actions and management strategies) is different from that adopted by the European Landscape Convention in that it allows to arrive to concrete landuse guidelines for landowners and users (decisionmakers), and requires methods for defining and mapping "landscape areas" [6]. As its main mapping criteria, it relies on landforms, ecosystems and expressions of land use. Another take on mapping modern landscapes was proposed by the developers of the new European landscape classification, which classifies "landscape-type systems" by looking at elevation, land use and climate [27].

Table 1. Calculating the degree of socioeconomic conditionality of landscape genesis.

\begin{tabular}{|c|c|c|c|c|c|c|}
\hline $\begin{array}{c}\text { Forest } \\
\text { coverage } \\
(\% \text { of total } \\
\text { area) } \\
\end{array}$ & $\begin{array}{l}\text { Agricultural } \\
\text { use } \\
\text { (\% of total } \\
\text { area) } \\
\end{array}$ & $\begin{array}{l}\text { Land under } \\
\text { construction } \\
\text { (\% of total } \\
\text { area) } \\
\end{array}$ & $\begin{array}{l}\text { Uncultivated } \\
\text { land } \\
\text { (\% of total } \\
\text { area) } \\
\end{array}$ & $\begin{array}{c}\text { Pasture } \\
\text { coverage }\end{array}$ & $\begin{array}{l}\text { Total } \\
\text { points }\end{array}$ & $\begin{array}{c}\text { Degree Socioeconomic } \\
\text { conditionality of } \\
\text { contemporary } \\
\text { landscape genesis }\end{array}$ \\
\hline$\geq 70$ & $\leq 5$ & $\leq 1$ & $\geq 8$ & $<20$ & $\leq 10$ & Very low \\
\hline $50-70$ & $5-15$ & $1-2$ & $4-8$ & $20-40$ & $11-13$ & Low \\
\hline $30-50$ & $15-25$ & $2-4$ & $2-4$ & $\geq 40$ & $14-16$ & Average \\
\hline $10-30$ & $25-35$ & $4-8$ & $1-2$ & Not calculated & $17-19$ & High \\
\hline$\leq 10$ & $\geq 35$ & $\geq 8$ & $\leq 1$ & Not calculated & $>20$ & Very high \\
\hline
\end{tabular}

As we can see, most of the authors share the opinion that regional landscape zoning should account for all kinds of factors - both natural and anthropogenic, since at that level socioeconomic conditioning plays the most important role, and the main landscape-forming systems are those of settlement and land use. Natural factors of landscape formation do prevail on poorly cultivated and scarcely populated areas. It illustrates spatial heterogeneity of social phenomena, since a decision not to develop a territory to its full capacity at any given moment is a stage of development of social systems and a feature of landscape-related regional policy. Thus, the state of modern landscape is directly dependent on the degree of its development, which is determined by socioeconomic factors. To rank the territories 
depending on these factors, we propose to use an indicator of socioeconomic conditionality of landscape genesis.

Socioeconomic conditionality indicator is a synthetic tool that accounts for anthropogenic differentiation of territorial units. It consists of five components: average density of the population, forest and/or pasture coverage and agricultural use, construction (industrial or residential) and road density, and share of areas unaffected by human activity (bare rocks, sands, wetlands, glaciers, etc.); in Europe, most of the latter would belong to protected lands. All data needed to calculate the indicator is available from the Eurostat and National Statistical Offices [36-48]. Indicator value is calculated as shown in the table below (see Table 1). The higher the value of the socioeconomic conditionality indicator, the greater is the role of social factors in landscape genesis that change the existing landscape through resettlement and land use.

\section{RESULTS AND DISCUSSION}

To determine the key factors of landscape development for specific territories, we calculated socioeconomic conditionality indicators for the countries of the Baltic macroregion and their administrative units (Fig. 1).

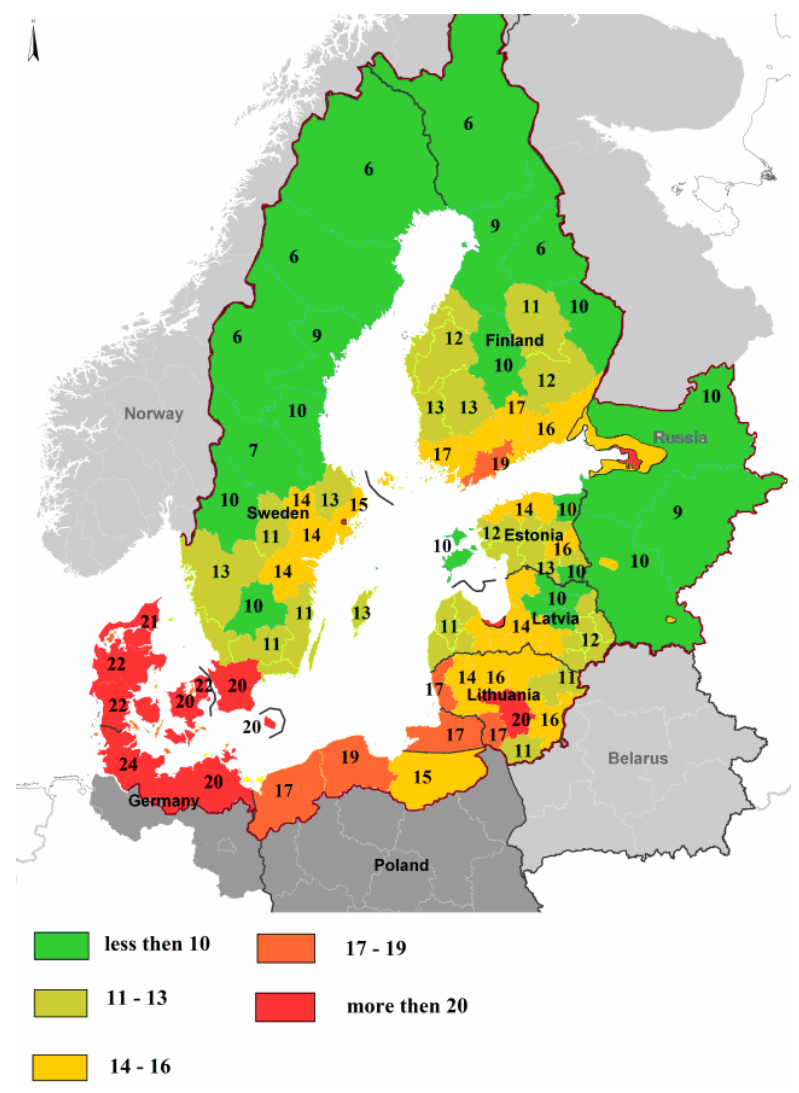

Fig. 1. Socioeconomic conditionality indicators for the regional units of the Baltic macroregion.
The map above shows that areas with low socioeconomic conditionality of contemporary landscape genesis are located in the northern territories of Sweden and Finland, can be found in Latvia, Estonia and in the Leningrad, Novgorod and Pskov regions. Areas with high socioeconomic conditionality can be found in Denmark, Germany, southern Sweden (Skåne) and southeastern Baltic. Settlement and land use are the main factors of landscape genesis for these territories.

Thus, for those Baltic macroregion areas demonstrating high socioeconomic conditionality of landscape genesis, a comparative geographical analysis of contemporary settlement and land use patterns was carried out.

Territories where modern landscape genesis is caused exclusively or mainly by social factors currently demonstrate the following settlement trends: sustainable population growth stimulated both by natural growth and incoming migration; development of urban agglomerations; sustaining established settlement patterns by relying on the development of rapid transportation systems. These territories include Denmark, northern Germany, the Western Pomeranian and Pomeranian voivodeships in Poland, southern Sweden (Skåne), part of Lithuania, and large urban agglomerations (St. Petersburg, Stockholm, Helsinki). These regions share development patterns, but also have some land use features that make it possible for them to be divided into two groups:

a). Areas of intensive residential and industrial land use. This group includes the centres of large urban agglomerations, as well as the western part of Northern Germany. EU-LUPA project has established that modern land use patterns in Europe date back to the previous century, with functional zoning formed after the Second World War, so at present these agglomerations can be characterized as mature with changes only occurring inside the existing structure.

b). Territories of intensive residential and agricultural land use. This group includes the territories of the western part of the Baltic region - most of Denmark, Skåne province in Sweden, part of Lithuania, with increasing evidence allowing to add the Kaliningrad region, Western Pomeranian voivodeship and part of the Pomeranian voivodeship of Poland to this group as well. The territories in this group enjoy a mature cultural landscape, which needs to be protected along with natural territories.

c). Lands with average socioeconomic conditionality of landscape genesis are not as homogeneous as lands in the group discussed before. This group includes the Warmia and Mazury 
voivodeship of Poland, a large part of Lithuania, central Latvia (the vicinity of Riga and Jurmala), the Harju and Tartu provinces in Estonia, the east of central Sweden, southern Finland, and the suburban areas of St. Petersburg. Here, population growth is insignificant or absent, with natural increase either negative or zero, and the existing growth (where it exists) provided due to the migration inflow; the basic population frame is not stable, with cities of less than 5 thousand people, as well as small rural settlements and farms, falling into the "risk group". Based on the characteristics of land use, we can further break these territories into:

$\mathrm{c}_{1}$ ). Areas of medium intensity land use with a combination of agricultural, forestry and residential development. This group includes part of Lithuania, the suburbs of Riga in Latvia, Tallinn in Estonia, part of the Leningrad region, part of the Pomeranian voivodeship and the western part of the Warmia and Mazury voivodeship of Poland. These territories are characterized by an increasing share of residential landscapes and decreasing importance of agricultural and forestry development.

$\mathrm{c}_{2}$ ). Territories of polarized land use - a combination of areas with land use of different intensity: the areas of intensive residential development are combined with the areas of agricultural development of medium intensity and protected landscapes. This group includes the eastern part of the Warmia and Mazury voivodeship and the east of central Sweden - the Baltic counties of Blekinge, Kalmar, Östergötland, Uppsala, Kronoberg, the islands of Öland and Gotland.

$c_{3}$ ). Territories with low intensity of land use associated with compression of socioeconomic space and depopulation. Such areas, though small, can be found in the Swedish counties of Kronoberg, Kalmar, on the island of Gotland, on some Danish islands and on Bornholm, the Lithuanian inland, on the border regions of the Warmia and Mazury voivodeship, as well as on the periphery of the St. Petersburg urban agglomeration.

According to the degree of socioeconomic conditionality of modern development of landscapes in the developed territories, it is possible to allocate new landscape areas. This grid of the new landscape zoning is not used autonomously, but is superimposed on the existing grid of natural-geographical zoning. At this level, public systems (systems of settlement and land use) acquire special significance for landscape genesis and determine the appearance of modern landscapes. Depending on the degree of influence of these systems (degree of development) on naturally connected territories, different modern landscape areas may develop over time.

\section{CONCLUSION}

The appearance and structure of contemporary landscape are the result of natural and anthropogenic influence, with the main factor of environment differentiation at the regional level being the human activity, specifically - settlement patterns and land use. In this study, we introduced a synthetic socioeconomic conditionality indicator to differentiate administrative and territorial units and to improve landscape zoning. The indicator was then used to assess territories of the Baltic macroregion. We found that northern and northeastern regions tend to demonstrate lower degrees of social conditionality, as opposed to southern and southwestern areas with higher indicator values for anthropogenic landscape genesis. Settlement patterns and land use are proposed to be the main factors of landscape genesis for these territories.

Understanding the state of contemporary landscapes is crucial for spatial planning, and the proposed system of landscape zoning can ensure sustainable territorial development in the future. The proposed indicator of socioeconomic conditionality, calculated with available statistical data, can be used at different hierarchical levels - from the level of the whole country and the macroregion, to the municipal authority. Another advantage of the index is its use for zoning within administrative boundaries (in contrast to natural landscape systems whose boundaries do not coincide with administrative ones, which complicates landscape management). These factors allow us to consider the proposed system of territorial zoning to be a convenient tool for spatial planning.

\section{REFERENCES}

[1] Beek, R. van, Louwen, A. (2012), Urnfields on the move: Testing burial site-settlement relations in the eastern Netherlands (c. 1100-50o BC), In: Archäologisches Korrespondenzblatt, vol. 42, issue 1.

[2] Bikbov, A. (2002), Socialnoe Prostranstvo kak Fizicheskoe: Illuzii i Ulovki [Social Space as Physical Space: Tricks and Illusions], In: Otechestvennye Zapiski, vol. 6, issue 7, pp. 63-64.

[3] Borisov, B. (2015), Spatial planning in regional planning of agricultural lands and rural areas. Bulg. J. Agric., Sci., 21: 751-756.

[4] Cullum C., Rogers K., Brierly G., Witkowsky Ed. (2016), Ecological classification and mapping for landscape management and science: Foundations for 
the description of patterns and processes, Progress in Physical Geography, 2016, vol. 40 (1), pp. 38-65.

[5] Dietrich, M. (2004), Reflections on the intelligence of natural systems, in Cultural landscapes, in Cultural Landscapes and Land Use, In: M. Dietrich, J. V. Straaden (ed.), The Nature Conservation - Society Interface, Kluwer Academic Publishes, USA.

[6] Erikstad, L., Uttakleiv, L. A., Halvorsen, R. (2015), Characterisation and mapping of landscape types, a case study from Norway, Belgeo, 3 | 2015, Online since 30 September 2015, connection on 02 October 2016. URL : http://belgeo.revues.org/17412 ; DOI : 10.400o/belgeo.17412

[7] Fedorov, G., Zverev Y., Karneyevets, V. (1997), Rossiyskiy Eksklavna Baltika [Russian Exclave on the Baltic Sea], Kaliningrad University Press, Russia. [8] Fedorov, G. M., Mikhailov, A. S., Kuznetsova, T. Yu. (2017), The influence of the sea on development of economics and distribution of the countries of the Baltic region, Baltic region, 2017, №2, pp. 7-27.

[9] Howard, P. (2011), An Introduction to Landscape, Ashgate, UK.

[10] Isachenko, A. (1991), Landscape science and physical geographical zoning, High School, Moscow.

[11] Isachenko, A. (2008), Landshaftnaya Struktura Zemli, Rasselenie, Prirodopolzovanie [Landscapes of the Earth: Settlement and Land Use], St. Petersburg University Press, Russia.

[12] Jackson, J. (1984), Discovering the vernacular landscape, Yale University Press, USA.

[13] Johansen, P. (2005), Kaugete aegade sära, Tartu (Ilmamaa). Available at: www.landscaperesearch. livingreviews.org. Last accessed: March, 11, 2017.

[14] Jones, M. (2007), The European Landscape Convention and the Question of Public Participation, Landscape Research, 32, 5, pp. 613-633.

[15] Karro, K., Mägi, M., Palang, H. (2014), Studying Past Landscapes: Lived, Reconstructed and Animated, In: Living Rev. Landscape Res., vol. 8, issue 1, doi:10.12942/lrlr-2014-1. Available at: http://www. livingreviews.org/lrlr-2014-1. Last accessed: March, 5, 2017.

[16] Karro, K. (2010), Kodavere Parish by Lake Peipus: The Development of the Cultural Landscape During the Iron Age, In: Archaeologia Baltica, vol. 14, pp. 184-196.

[17] Karro, K. (2013), Ruptured Space and Time in Lahepera Burial Site in Eastern Estonia, In: Archaeologia Baltica, vol. 19, pp. 32-41.

[18] Keough, S. (2013), Cultural Landscape. Available at: www.oxfordbibliographies.com. Last accessed: February, 7, 2017.

[19] Kuster, H. (2004), Cultural landscapes - an introduction, in Cultural landscapes, in Cultural Landscapes and Land Use, In: M. Dietrich, J. V. Straaden (ed.), The Nature Conservation - Society Interface, Kluwer Academic Publishes, USA, pp. 1-12.
[20] Longstreth, R. (2008), Balancing nature and heritage, In: R. Longstreth (ed.), Preservation practice. Cultural Landscapes, University of Minnesota, USA, pp. 1-15.

[21] McHarg, I. (1969), Design with Nature; Doubleday/Nature History Press: New York, NY, USA

[22] Mezhevich, N. M., Kretinin, G. V., Fedorov, G. M. (2016), On the question of the economic and geographical structuring of the Baltic region, the Baltic region, 2016, № 3, p. 15-29.

[23] Mejer, D. (2013), From nature to culture: landscape and settlement history of the North-Sea coast of Schleswig-Holstein, Germany, in Landscapes or seascapes? : The history of the coastal environment in the North Sea area reconsidered, Brepols Publishers, Belgium, pp. 85-110. Available at: http://www. brepolsonline.net/doi/book/10.1484. Last accessed: February, 15, 2017.

[24] Mitchell, D. (2000), Cultural Geography: A Critical Introduction, Blackwell, USA.

[25] Monaghan, W. G., Lovis, W. A. (2005), Modeling Archaeological Site Burial in Southern Michigan: A Geoarchaeological Synthesis: East Lansing, Michigan State University Press, USA., pp. 41-60.

[26] Mägi, M. (2002), Pürkonnad ja keskused: Asustus muinasaja lõpu ja varakeskaegsel Saaremaal arheoloogiliste, inimgeograafiliste ning ajalooliste allikate andmeil, In: V. Lang(ed.), Keskus - tagamaa ääreala: Uurimusi asustushierarhia ja võimukeskuste kujunemisest Eestis, Muinasaja Teadus / Research into Ancient Times, vol. 11, Teaduste Akadeemia Kirjastus, Estonia, pp. 169-232.

[27] Mücher, C. A., Kijn, J. A., Wascher, D. M., Joop, H. J., Schaminée, J. H. J. (2010), A new European Landscape Classification (LANMAP): A transparent, flexible and user-oriented methodology to distinguish landscapes, Ecological Indicators, 10, pp. 87-103.

[28] Rippon, S. (2012), Making Sense of an Historic Landscape, Oxford University Press, UK.

[29] Sarlöv Herlin, I. (2007), The interface with landscape ecology, in JONES M., HOWARD P.,OLWIG K.R., PRIMDAHL J. \& SARLÖV HERLIN I. (2007), Multiple interfaces of the European Landscape Convention, Norwegian Journal of Geography, 61, pp. 210-211.

[30] Sauer, C. O. (1925), The Morphology of Landscape. University of California Publications in Geography 2 (2):19-53 URL: http://geog.uoregon.edu/ amarcus/geog620/readings/sauer_1925_morphology_ of_landscape.pdf

[31] Schryver, J. G. (2015), Converting the land of the Irish: Saint Patrick, the Church, and the Irish landscape. Church and Settlement in Ireland: Landscape, Life and Legacy, Ireland, Available at: http://irishsettlement.ie 
[32] Spek, T. (2012), Landscape research in a world of domesticated landscapes: the role of values, theory and concepts, Quaternary International, vol. 251, pp. 117-124.

[33] Swinnerton, G., Buggey, S. (2004), Protected Landscapes in Canada: Current Practice and Future Significance, In: The George Wright Forum, vol. 21, issue 2, pp. 78-92.

[34] Tishkov, V. (2003), Kulturny Smysl Prostranstva [Landscape's Cultural Meaning], Keynote presentation at the Vth All-Russian Congress of Ethnologists and Anthropologists, Omsk. Available at: www.ethnonet.ru/lib/o803-02.html. Last accessed: April, 13, 2017.

[35] Wallech, B. (2005), Understanding the Cultural Landscape, Guilford, USA. Available at: https://www.questia.com/library/119374233/understa nding-the-cultural-landscape. Last accessed: Marth, 7, 2017.

[36] *** Eurostat Statistics, https:/ ec.europa.eu/Eurostat

[37] https:/ knoema.com

[38] https:/ stat.fi

[39] https:/ scb.se

[40] https:/ dst.dk

[41] https:/ statistic-portal.de

[42] https:/ stat-gov.pl

[43] https:/ osp.stat.gov.lt

[44] https:/ csb.gov.lv

[45] https:/ stat.ee

[46] https:/ stat.fi

[47] https:/ rosreestr.ru

[48] https:/ gks.ru+ 